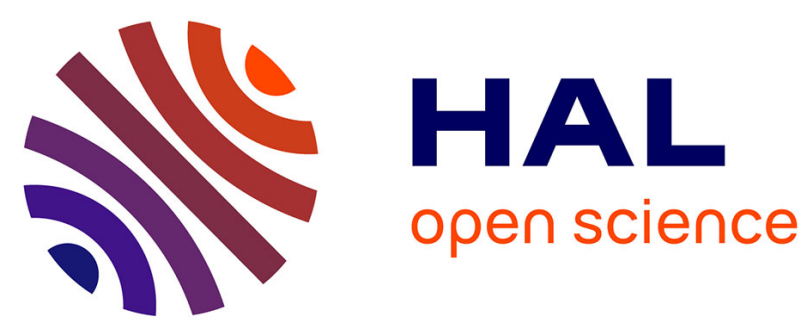

\title{
Cytokine modulation by PX differently affects specific acute phase proteins during sepsis in rats
}

\author{
Laure Voisin, Denis Breuillé, Benoît Ruot, Cécile Ralliere, Fabienne
}

Rambourdin, Michel Dalle, Christiane Obled

\section{To cite this version:}

Laure Voisin, Denis Breuillé, Benoît Ruot, Cécile Ralliere, Fabienne Rambourdin, et al.. Cytokine modulation by PX differently affects specific acute phase proteins during sepsis in rats. AJP - Regulatory, Integrative and Comparative Physiology, 1998, 275 (5), pp.R1412-R1419. hal-02695995

\section{HAL Id: hal-02695995 \\ https://hal.inrae.fr/hal-02695995}

Submitted on 1 Jun 2020

HAL is a multi-disciplinary open access archive for the deposit and dissemination of scientific research documents, whether they are published or not. The documents may come from teaching and research institutions in France or abroad, or from public or private research centers.
L'archive ouverte pluridisciplinaire $\mathbf{H A L}$, est destinée au dépôt et à la diffusion de documents scientifiques de niveau recherche, publiés ou non, émanant des établissements d'enseignement et de recherche français ou étrangers, des laboratoires publics ou privés. 
Laure Voisin, Denis Breuillé, Benoît Ruot, Cécile Rallière, Fabienne Rambourdin, Michel Dalle and Christiane Obled

Am J Physiol Regulatory Integrative Comp Physiol 275:1412-1419, 1998.

You might find this additional information useful...

This article cites 43 articles, 20 of which you can access free at:

http://ajpregu.physiology.org/cgi/content/full/275/5/R1412\#BIBL

This article has been cited by 5 other HighWire hosted articles:

Reduction of low grade inflammation restores blunting of postprandial muscle anabolism and limits sarcopenia in old rats

I. Rieu, H. Magne, I. Savary-Auzeloux, J. Averous, Céc. Bos, M. A. Peyron, L. Combaret and D.

Dardevet

J. Physiol., November 15, 2009; 587 (22): 5483-5492.

[Abstract] [Full Text] [PDF]

Pentoxifylline reduces fibrin deposition and prolongs survival in neonatal hyperoxic lung injury

S. A. J. ter Horst, G. T. M. Wagenaar, E. de Boer, M. A. van Gastelen, J. C. M. Meijers, B. J.

Biemond, B. J. H. M. Poorthuis and F. J. Walther

J Appl Physiol, November 1, 2004; 97 (5): 2014-2019.

[Abstract] [Full Text] [PDF]

Acute myocardial infarction induces hypothalamic cytokine synthesis

J. Francis, Y. Chu, A. K. Johnson, R. M. Weiss and R. B. Felder

Am J Physiol Heart Circ Physiol, June 1, 2004; 286 (6): H2264-H2271.

[Abstract] [Full Text] [PDF]

Synthesis rate of plasma albumin is a good indicator of liver albumin synthesis in sepsis

B. Ruot, D. Breuille, F. Rambourdin, G. Bayle, P. Capitan and C. Obled

Am J Physiol Endocrinol Metab, August 1, 2000; 279 (2): E244-E251.

[Abstract] [Full Text] [PDF]

Pentoxifylline prevents the transition from the hyperdynamic to hypodynamic response during sepsis

S. Yang, M. Zhou, D. J. Koo, I. H. Chaudry and P. Wang

Am J Physiol Heart Circ Physiol, September 1, 1999; 277 (3): H1036-H1044.

[Abstract] [Full Text] [PDF]

Medline items on this article's topics can be found at http://highwire.stanford.edu/lists/artbytopic.dtl

on the following topics:

Biochemistry .. Acid Glycoproteins

Biochemistry .. Albumins

Physiology .. Fibrinogen

Biophysics .. Tumor Necrosis Factor

Oncology .. Interleukins

Physiology .. Rats

Updated information and services including high-resolution figures, can be found at:

http://ajpregu.physiology.org/cgi/content/full/275/5/R1412

Additional material and information about American Journal of Physiology - Regulatory, Integrative and Comparative Physiology can be found at:

http://www.the-aps.org/publications/ajpregu

This information is current as of September 8, 2010 .

The American Journal of Physiology - Regulatory, Integrative and Comparative Physiology publishes original investigations that illuminate normal or abnormal regulation and integration of physiological mechanisms at all levels of biological organization, ranging from molecules to humans, including clinical investigations. It is published 12 times a year (monthly) by the American Physiological

Society, 9650 Rockville Pike, Bethesda MD 20814-3991. Copyright ( 1998 by the American Physiological Society. ISSN: 0363-6119,

ESSN: 1522-1490. Visit our website at http://www.the-aps.org/. 


\title{
Cytokine modulation by PX differently affects specific acute phase proteins during sepsis in rats
}

\author{
LAURE VOISIN, ${ }^{1}$ DENIS BREUILLÉ, ${ }^{2}$ BENOÎT RUOT, ${ }^{1}$ CÉCILE RALLIÈRE, ${ }^{1}$ \\ FABIENNE RAMBOURDIN, ${ }^{1}$ MICHEL DALLE, ${ }^{3}$ AND CHRISTIANE OBLED ${ }^{1}$ \\ ${ }^{1}$ Centre de Recherche en Nutrition Humaine et Institut National de la Recherche \\ Agronomique, Unité d'Etude du Métabolisme Azoté, 63122 Ceyrat; 'Laboratoire \\ de Physiologie du Dével oppement, Université Blaise Pascal, Aubière Cedex 63177, \\ France; and ${ }^{2}$ Centre de Recherches Nestlé, CH 1000 Lausanne 26, Switzerland
}

\begin{abstract}
Voisin, Laure, Denis Breuillé, Benoît Ruot, Cécile Rallière, Fabienne Rambourdin, Michel Dalle, and Christiane Obled. Cytokine modulation by PX differently affects specific acute phase proteins during sepsis in rats. Am. J . Physiol. 275 (Regulatory I ntegrative Comp. Physiol. 44): R1412-R1419, 1998.-To explore the regulation of the acute phase response in vivo, the effects of pentoxifylline (PX) treatment (100 mg/kg ip $1 \mathrm{~h}$ before infection) were investigated in infected and pair-fed rats 2 and 6 days after an intravenous injection of live bacteria (Escherichia coli). PX treatment prevented the increase in plasma tumor necrosis factor (TNF)- $\alpha$ (peak $1.5 \mathrm{~h}$ after the infection) and resulted in an 84 and $61 \%$ inhibition of plasma interleukin (IL)-1 $\beta$ and IL-6, respectively (peaks at $3 \mathrm{~h}$ ). Plasma corticosterone kinetics were not modified by the treatment. Infection increased $\alpha_{1}$-acid glycoprotein (AGP), $\alpha_{2}$-macrogl obul in (A2M), and fibrinogen plasma concentrations and decreased albumin levels. PX significantly reduced AGP plasma concentration as early as day 2 in infected animals but reduced A2M and fibrinogen plasma levels only at day 6 . The treatment had no effect on the al bumin plasma concentration. HepaticAGP and fibrinogen mRNA levels increased in infected rats, whereas those of $\mathrm{A} 2 \mathrm{M}$ were unchanged and those of albumin were decreased. Two days after infection, AGP and fibrinogen mRNA levels were reduced in treated infected animals. PX was ineffective in modifying those of $A 2 M$ and al bumin. These data demonstrate, in vivo, that different acute phase proteins are individually regulated in sepsis. The in vivo effects of $P X$ treatment support the hypothesis that TNF - $\alpha$ plays an important role in the regulation of AGP production, whereas other factors seem to be involved in the regulation of A2M, fibrinogen, and albumin expression.
\end{abstract}

tumor necrosis factor; interleukin-1; interleukin-6

AMONG OTHER METABOLIC disturbances, sepsis causes a marked loss of weight and body proteins, muscle wasting, and a hepatic acute phase response. Total liver protein synthesis was markedly enhanced $(11,44)$, mainly due to an increased synthesis of exported proteins (acute phase proteins; see Ref. 44). Thus the liver response results in a concomitant increase in the circulating levels of these proteins. However, the levels of some plasma proteins such as albumin, named negative acute phase proteins, decrease $(33,42)$.

The costs of publication of this article were defrayed in part by the payment of page charges. The article must therefore be hereby marked "advertisement" in accordance with 18 U.S.C. Section 1734 solely to indicate this fact.
Cytokines, and especially tumor necrosis factor (TNF)- $\alpha$ (43) and interleukins-1 (IL-1; see Ref. 35) and 6 (IL-6; see Ref. 6), are considered to play key roles in the pathogenesis of sepsis. With respect to liver, administration of cytokines to healthy animals can reproduce the stimulation of protein synthesis $(5,13)$. The roles of cytokines in inducing individual acute phase protein changes have been studied extensively in various in vitro systems as hepatocyte primary cultures or hepatoma cell lines. Based on these studies, I L-6 appears to be the main cytokine regulating the expression of the majority of the acute phase protein genes, whereas $I L-1 \beta$ and TNF $-\alpha$ regulate a different set of genes (17, $29,33)$. Maximal expression of several acute phase protein genes is dependent on the presence of glucocorticoids (29). However, for a particular protein, different responses can be obtained in various cell systems (29), and the regulatory processes involved in the in vivo acute phase response might be much more complex. Some studies have been reported in which the role of IL-1 $(28,37)$ and IL-6 $(20,31)$ on the acute phase induction was studied in vivo. However, a major difficulty in defining the roles of various cytokines in vivo is their ability to induce each other $(35,43)$. Another approach, poorly documented in sepsis, consists of inhibiting the production or action of individual cytokines $(21,32,42)$.

TNF- $\alpha$ is the first cytokine to appear in the circulation after administration of endotoxin or living bacteria in various species (43). Thus TNF- $\alpha$ is thought to be a proximal mediator of the inflammatory response and most likely triggers the release of other secondary mediators, including other cytokines. Pentoxifylline $(P X)$, a methylxanthine derivative, has been demonstrated both in vitro and in vivo to suppress lipopolysaccharide (LPS)-induced TNF- $\alpha$ secretion $(12,30,39,41)$. PX may also modulate other cytokines, but this effect is morecontroversial $(30,39,41)$, and its effect on glucocorticoid level is unknown. Thus, in this study, we explored in vivo the effect of PX treatment on TNF - $\alpha, I L-1, I L-6$, and corticosterone levels in a rat model of gram-negative sepsis. Furthermore, we examined whether inhibition of TNF- $\alpha$ production could modulate the expression and plasma appearance of individual acute phase proteins during the acute septic phase ( 2 days postinfection) and the chronic septic phase ( 6 days postinfection).

\section{MATERIALS AND METHODS}

Animals. Male Sprague-Dawley rats (Iffa Credo, SaintGermain sur l'Arbresle, France) were individually housed in 
wire-bottom cages in a temperature-controlled room (22$23^{\circ} \mathrm{C}$ ) with a $12: 12$-h light-dark cycle. During a 6-day acdimatization period, all rats received a semisynthetic diet containing $12 \%$ protein distributed by an automatic device (12). Animals were weighed every morning, and food intake was measured every day.

At an initial body weight of $300 \mathrm{~g}$, rats were divided into the following four groups: infected rats (INF) and their pair-fed control (PF) and infected rats treated with PX (PX-INF) and their pair-fed controls treated with $P X(P X-P F)$. The INF group received saline intraperitoneally $1 \mathrm{~h}$ before injection of Escherichia coli (serotype 0153- $\mathrm{K}^{-}-\mathrm{H}^{-} ; 7 \times 10^{8}$ colonyforming units) into a lateral tail vein. Control animals of the I NF group (PF) received saline intraperitoneally $1 \mathrm{~h}$ before an intravenous saline injection; because infection dramatically decreases food intake (11), the animals were pair fed to the intake of infected rats. In the PX-INF group, PX (100 mg/kg) was injected intraperitoneally $1 \mathrm{~h}$ before bacteria administration. Control animals of the PX-INF group (PX-PF) received an equal volume of PX injected intraperitoneally $1 \mathrm{~h}$ before saline intravenous injection. Because PX treatment increases voluntary food consumption in infected rats, this control group (PX-PF) was pair fed to PX-INF animals. Pair feeding was conducted as previously described (11). Animals were weighed every day until the completion of the study. Animals of each group were studied at days 2 and 6 after the infection, which represents, respectively, the acute and chronic septic phases previously described (11). In infected rats, the mortality was $7 \%$, and there was no mortality in infected rats pretreated with PX. After anesthesia with pentobarbital sodium ( $6.0 \mathrm{mg} / 100 \mathrm{~g}$ body $\mathrm{wt})$, gastrocnemius and soleus muscles were dissected and weighed. Blood samples were collected into EDTA tubes, and plasma was stored at $-20^{\circ} \mathrm{C}$ for acute phase protein assays. Liver samples were taken by freeze clamping and kept at $-80^{\circ} \mathrm{C}$ until analysis. The protocol was approved by the Ethics Committee of the Institute National de la Recherche Agronomique and was conducted in conformity with the guiding principles in the care and use of laboratory animals.

TNF- $\alpha-$, IL-1 $\beta-$, and IL-6-likebioactivity and corticosterone assays. A preliminary kinetic study of TNF $-\alpha, I L-1 \beta$, and IL-6 production in plasma from 1 to $24 \mathrm{~h}$ after the infection showed that maximal plasma levels occurred at $1.5 \mathrm{~h}$ for TNF $-\alpha$ and 3 $\mathrm{h}$ for IL-1 $\beta$ and IL-6 after bacteria administration (Fig. 1). Thus blood samples were collected in a lateral tail vein 1.5 and $3 \mathrm{~h}$ after the infection in heparinized tubes, and plasma was stored at $-80^{\circ} \mathrm{C}$ for TNF $-\alpha$ and IL- $1 \beta$ and at $-20^{\circ} \mathrm{C}$ for IL- 6 assays. TNF $-\alpha$ and IL-1 plasma concentrations were measured by using ELISA kits, according to the manufactur-

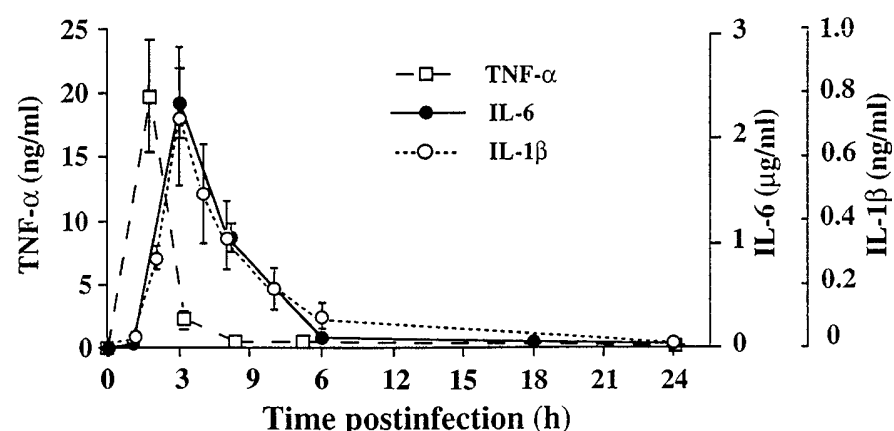

Fig. 1. Time course of plasma tumor necrosis factor (TNF)- $\alpha$, interleukin (IL)-1 $\beta$, and IL-6 concentrations within $24 \mathrm{~h}$ after infection. TNF- $\alpha$ and IL-1 $\beta$ were measured with the use of ELISA kits Biological activity of IL-6 was estimated in a bioassay using the B-9 hybridoma cell line. Values are means \pm SE for 6-8 animals. er's instructions (Genzyme, Cambridge, MA, and Amersham, Bucks, UK, respectively). Biological activity of IL-6 was estimated in a bioassay using the B-9 hybridoma cell line (1). Briefly, B-9 cells $(5,000 / 100 \mu \mathrm{l})$ were cultured in 96-well microtiter plates with serial dilutions of test samples (22). The IL-6 standard was human recombinant I L-6 (no. 89/548; National Institute for Biological Standards and Control, Hertfordshire, UK), which was serially diluted. After $48 \mathrm{~h}$ of incubation at $37^{\circ} \mathrm{C}$ with $5 \% \mathrm{CO}_{2}, 20 \mu$ of 3-(4,5-dimethylthiazol-2-yl)-5-(3-carboxymethoxyphenyl)-2-(4-sulfophenyl)-2Htetrazolium, inner salt $(2 \mathrm{mg} / \mathrm{ml})$ was added to each well in the presence of phenazine methosulfate and incubated for an additional $2 \mathrm{~h}$ to determine cell proliferation (16). The watersoluble formazan product was quantitated at $490 \mathrm{~nm}$ in an MR 700 microplate reader (Dynatech Laboratories, Guernsey, UK). Plasma corticosterone concentrations were assayed by RIA as described by Pradier and Dalle (34).

Acute phase protein concentration. Fibrinogen, $\alpha_{1}$-acid glycoprotein (AGP), $\alpha_{2}$-macrogl obul in (A2M), and al bumin plasma levels were measured by singleradial diffusion, using anti-rat fibrinogen and albumin from Cappel and anti-rat AGP and A2M produced in thelaboratory.

N orthern blot analysi s. Total RNA was extracted from $0.2 \mathrm{~g}$ of liver by the method of Chomczynsky and Sacchi (14). Twenty micrograms of RNA wereelectrophoresed in formaldehyde agarose gels (1\%) and transferred electrophoretically to nylon membranes (GeneScreen; NEN Research Products, Boston, MA). RNA was covalently bound to the membrane by ultraviolet cross-linking. Membranes were hybridized with cDNA probes AGP (36), A2M (no. 63099; American Type Culture Collection, Rockville, MD; see Ref. 19), $\alpha$-fibrinogen (7), and albumin (25). Hybridizations were conducted overnight at $65^{\circ} \mathrm{C}$ with [32P]CDNA fragments labeled by random priming. After washing at the same temperature, filters were autoradiographed at $-80^{\circ} \mathrm{C}$ with intensifying screens on Hyperfilm-MP (Amersham). After stripping of the different probes, the filters were reprobed with a mouse $18 \mathrm{~S}$ ribosomal probe (no. 63178; American Type Culture Collection). Autoradiographic signals were quantified by digital image processing and analysis (NIH I mage 1.54) and normalized using the corresponding 18S rRNA signals to correct for uneven loading.

Statistics. All data are expressed as means \pm SE. The significance of differences was analyzed by one-way ANOVA and by Student's t-test where appropriate. Differences among means were considered significant at $\mathrm{P}<0.05$.

\section{RESULTS}

Food intake, body weight, and muscleweight. Results presented in Figs. 2 and 3 show values obtained on rats studied for 6 days after the infection. Similar results were observed during the acute period in the group killed at day 2. Infection decreased food intake, especially during the acute phase period since rats ate only $5-15 \%$ of the preinfection intake (20-25 g). Thereafter, food intake of infected animals gradually increased to reach $75 \%$ of preinfection food consumption at the end of the study. Pretreatment of animals with PX before infection reduced anorexia, mainly at days 2 to 4 after infection compared with untreated rats (Fig. 2). On day 2 postinfection, the decrease of body weight observed in infected rats (INF) was significantly higher $(27.5 \%)$ than in pair-fed animals (PF; Fig. 3), and the difference between these two groups strongly increased until 6 days after infection. By contrast, the body weight loss of 


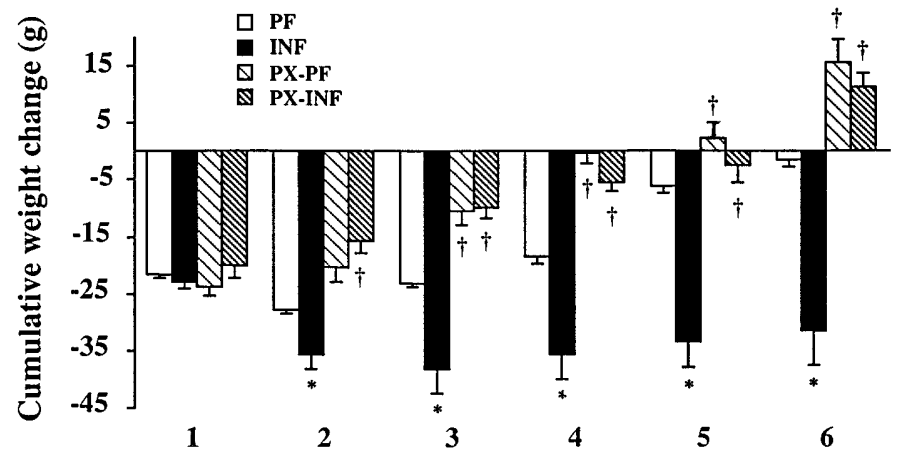

Time postinfection (d)

Fig. 2. Effect of pentoxifylline (PX) treatment on daily food intake within 6 days postinfection. Values are means \pm SE for $6-11$ animals. INF, infected rats; PF, pair-fed controls of INF rats; PX-INF, infected rats treated with PX; PX-PF, pair-fed controls treated with PX of $P X-I N F$. $* P<0.05$ vs. respective $P F$ animals; $d$, days. $† P<0.05$ vs. respective animals without $\mathrm{PX}$ treatment.

septic rats treated with $\mathrm{PX}$ (PX-INF) was always similar to that of their pair-fed controls (PX-PF). Moreover, PX-INF rats began to gain weight on day 3 although INF rats continued to lose weight. Thus, 6 days after infection, septic rats had lost $\sim 32 \mathrm{~g}$, and infected rats treated with $P X$ had regained $\sim 10 \mathrm{~g}$ body weight compared with their initial body weight.

During the acute phase, the weight of the various muscles studied was significantly reduced in infected animals compared with control rats ( 15 and $13 \%$ for gastrocnemius and soleus, respectively; Table 1 ). In the same septic phase, similar decreases were observed for infected animals treated with PX compared with their pair-fed controls $(\sim 13 \%)$. Six days postinfection, the observed atrophy of gastrocnemius and soleus muscles in INF rats was more severe (30 and $17 \%$, respectively; Table 1). By contrast, PX treatment reduced the atrophy of gastrocnemius ( $12 \%$ vs. respective pair-fed rats) and abolished the atrophy of soleus muscle.

TNF- $\alpha-$, I L-1 $\beta-$, and I L-6-likebioactivity and glucocorticoid plasma levels. Administration of PX $1 \mathrm{~h}$ before infection suppressed the rise of the plasma TNF- $\alpha$ level (by $99 \%$; Table 2). PX treatment induced a reduction of 84 and $61 \%$ of plasma IL-1 $\beta$ - and IL-6-like bioactivity

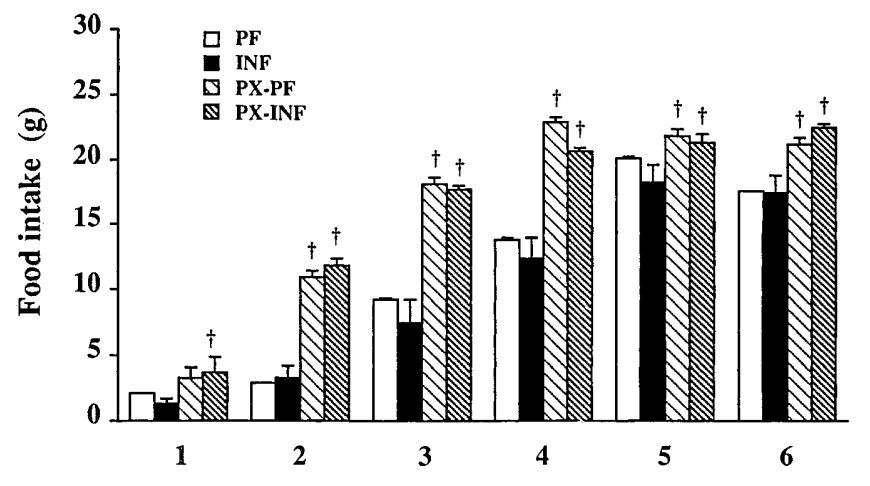

Time postinfection (d)

Fig. 3. Effect of $P X$ treatment on cumulative weight change within 6 days postinfection. Values are means \pm SE for 6-11 animals. $† P<$ 0.05 vs. respective animals without $P X$ treatment. concentrations, respectively, $3 \mathrm{~h}$ after infection (Table 2). In INF rats, plasma corticosterone levels were significantly higher $4 \mathrm{~h}$ after bacteria injection and were similar to normal values 24 and $48 \mathrm{~h}$ after the infectious stress (Fig. 4). PX treatment did not prevent the sepsis-induced increase in plasma corticosterone levels (Fig. 4).

Acute phase proteins. A2M, AGP, and fibrinogen concentrations were significantly increased 2 days after the infection (29-, 59-, and 2.3-fold, respectively) and 6 days after the infection (18-, 14-, and 2-fold, respectively) in INF rats compared with PF controls (Table 3). By contrast, albumin concentration was significantly reduced 2 and 6 days postinfection ( 45 and $54 \%$, respectively). Infection significantly increased hepatic mRNA concentrations for AGP (19- and 8-fold, at days 2 and 6 , respectively; Fig. 5) and fibrinogen (57 and $37 \%$ at days 2 and 6 , respectively; Fig. 6). A2M mRNA levels increased significantly only on day 6 postinfection but more moderately than those of AGP (55\%; Fig. 5). By contrast, al bumin mRNA levels were decreased by infection (50 and 57\% at days 2 and 6 , respectively; Fig. 6).

Administration of PX significantly decreased by $29 \%$ the rise in plasma AGP concentration in INF rats as early as 2 days after bacteria injection but did not significantly affect the increase in A2M and fibrinogen levels (Table 3). However, 6 days postinfection, the concentrations of these three positive acute phase proteins were significantly decreased in PX-INF rats compared with I NF rats (65, 50, and $21 \%)$. No modification of the decrease of albumin concentration was observed with PX administration (Table 3). PX treatment reduced the increase in AGP and fibrinogen mRNA levels in PX-INF rats compared with nontreated infected rats 2 days after infection (Figs. 5 and 6), although they were not significantly different in PXINF rats and nontreated infected rats on day 6 postinfection. PX treatment did not induce any significant variation of the A2M and al bumin mRNA levels 2 and 6 days after infection (Figs. 5 and 6).

\section{DISCUSSION}

PX has been shown to increase animal survival in lethal models of infection (38) and to block LPS fever (30). The beneficial effects of PX in sepsis have been attributed to its ability to inhibit the production of TNF - $\alpha$ in vitro $(39,41)$ and in vivo $(12,30,38)$. TNF - $\alpha$ is the first cytokine to appear in the plasma after endotoxemia or infection, and it induces the synthesis and release of other mediators, such as IL-1 and IL-6, generating a cytokine cascade (43). The neutralization of endogenous TNF- $\alpha$ with anti-TNF- $\alpha$ antibodies greatly diminishes the increases in IL-1 $\beta$ and IL- 6 in endotoxemia and sepsis $(18,42)$. Our results demonstrate that PX produced similar effects, decreasing IL-1 $\beta$ and IL-6 plasma levels $3 \mathrm{~h}$ after the infection. H owever, the effect of PX on the I L-1 $\beta$ plasma level was greater than on the I L- 6 plasma level. I L- 6 is produced later than TNF- $\alpha$, and more or less simultaneously with IL-1 $\beta$, both of which induced IL-6 $(6,22)$. Thus the 
Table 1. Effect of PX treatment on muscle weights 2 and 6 days postinfection

\begin{tabular}{|c|c|c|c|c|c|c|c|c|}
\hline & \multicolumn{8}{|c|}{ Days Postinfection } \\
\hline & \multicolumn{4}{|c|}{2} & \multicolumn{4}{|c|}{6} \\
\hline & $\mathrm{PF}$ & INF & PX-PF & PX-INF & $\mathrm{PF}$ & INF & PX-PF & PX-INF \\
\hline $\begin{array}{l}\text { Gastrocnemius, g } \\
\text { Soleus, mg }\end{array}$ & $\begin{array}{l}1.69 \pm 0.02 \\
125 \pm 3\end{array}$ & $\begin{array}{l}1.44 \pm 0.02 * \\
109 \pm 2 *\end{array}$ & $\begin{array}{l}1.81 \pm 0.03 \dagger \\
128 \pm 6\end{array}$ & $\begin{array}{l}1.56 \pm 0.03^{*} \dagger \\
112 \pm 4^{*}\end{array}$ & $\begin{array}{l}1.83 \pm 0.03 \\
121 \pm 11\end{array}$ & $\begin{array}{c}1.21 \pm 0.04 * \\
97 \pm 4^{*}\end{array}$ & $\begin{array}{l}1.91 \pm 0.04 \\
124 \pm 3\end{array}$ & $\begin{array}{l}1.68 \pm 0.03 * \dagger \\
120 \pm 2 \dagger\end{array}$ \\
\hline
\end{tabular}

Values are means \pm SE for 5 or 6 animals. INF, infected rats; PF, pair-fed control of INF rats; PX-INF, infected rats treated with pentoxifylline (PX); PX-PF pair-fed control treated with PX of PX-INF. $* P<0.05$, one-way ANOVA vs. respective pair-fed controls. $† P<0.05$, one-way ANOVA vs. respective infected animals.

remaining IL-1 $\beta$ can be sufficient to produce a large increase of IL-6 plasma level in PX-treated animals.

Plasma corticosterone levels were increased soon after administration of IL-1 $\beta(47)$ and LPS $(22,26)$, after cecum ligature and puncture in rats (23), or after bacteria injection as shown in our study. A novel result of this study is the inability of PX administration to modify glucocorticoid levels. Proinflammatory cytokines, like TNF- $\alpha$ and IL-1, were reported to increase glucocorticoid synthesis and rel ease via the stimulation of the hypothalamic-pituitary axis (29). The lack of effect of PX treatment on corticosterone plasma level may be the result of remaining $\mathrm{IL}-1 \beta$ and/or the presence of other factors sufficient to induce a maximum production of glucocorticoids, since pretreatment of turpentine-injected mice with anti-IL-1 receptor antagonist ( $\mathrm{ra}$ ) did not affect the increase in circulating corticosterone (21). Nevertheless, TNF- $\alpha$ did not appear to be the main mediator of corticosterone production in sepsis. Moreover, our results suggest that the mechanisms of PX action are independent of corticosterone levels or that corticosterone has only minor direct effects in sepsis.

PX administration reduced, but did not prevent, anorexia induced by infection, as previously observed in our laboratory (12) or by other s using TNF- $\alpha$ monoclonal antibody pretreatment in endotoxemic rats (42). These data are in agreement with the view that TNF $-\alpha$ and IL-1 $\beta$ have anorexic effects (45). PX treatment suppressed body weight difference between INF rats and their PF control over the entire course of the study. Thus the effect of infection on body weight change completely disappeared in infected treated animals. Moreover, muscle atrophy linked to infection was significantly reduced by PX treatment and even abolished at day 6 in soleus muscle. This rapid recovery of muscle weight of treated animals is consistent with the increase of protein synthesis $(12,15,27)$ and the inhibi-

Table 2. Effect of PX treatment on plasma TNF- $\alpha$ (measured 90 min after infection)-, IL-1 $\beta-$, and I L-6-likebi oactivity (measured $3 \mathrm{~h}$ after infection)

\begin{tabular}{llc}
\hline \hline & INF & PX-INF \\
\hline $\mathrm{TNF}-\alpha, \mathrm{ng} / \mathrm{ml}$ & $71.9 \pm 4.6$ & $0.6 \pm 0.1^{*}$ \\
$\mathrm{IL}-1 \beta, \mathrm{ng} / \mathrm{ml}$ & $1.38 \pm 0.48$ & $0.22 \pm 0.05^{*}$ \\
$\mathrm{IL}-6, \mu \mathrm{g} / \mathrm{ml}$ & $5.09 \pm 0.56$ & $1.98 \pm 0.40^{*}$ \\
\hline
\end{tabular}

Values are means \pm SE for $12-14$ animals. TNF $-\alpha$, tumor necrosis factor- $\alpha ; I L$, interleukin. $* P<0.05$ vs. infected animals. tion of proteolysis $(46,48)$ reported previously with inhibitors of TNF- $\alpha$ secretion or action and IL-Ira.

The acute phase response associated with sepsis is accompanied by changes of the plasma concentration of a large number of proteins. Increased rates of incorporation of radiolabeled amino acids into proteins suggest, at least in part, that the increase of the plasma concentration of acute phase proteins during inflammation or sepsis is due to increased rates of their synthesis (40). The regulation of protein synthesis may occur at different levels, including various steps in thetranscriptional and translational events. The analysis of mRNA levels and the measurement of transcription activity have provided evidence that transcriptional mechanisms play a central role in the regulation of expression of many acute phase proteins $(9,31,36)$. Our results are in agreement with this view for AGP and fibrinogen, since mRNA levels were increased 2 and 6 days after the infection. By contrast, we found no coordinated changes between mRNA levels and plasma concentration of $A 2 M$, suggesting that the genes of these three proteins may be partially regulated by different mechanisms during inflammation. However, the increase in A2M mRNA level could be achieved before 48 h (19). Moreover, hepatic mRNA levels for $A 2 M$ and AGP were found to increase to a maximum $24 \mathrm{~h}$ after LPS injection, with normal levels at $48 \mathrm{~h}$ for A2M but 10-fold over control values for AGP (42). Regulation of A2M may also occur on posttranscriptional levels, since Andus et al. (4) demonstrated that IL-6 markedly accel erated the secretion of A2M in hepatocyte primary cultures. For al bumin, hepatic mRN A level and plasma concentration were diminished by $\sim 50 \% 2$ and also 6 days after infection. Such correl ated decreases, suggesting that hypoal buminemia is due to a decreased synthesis of the protein, have been described 24-48 h after LPS and turpentine injections, but they were followed by recovery over the next $48-72 \mathrm{~h}(2,42)$. These results underline the long-lasting perturbations associated with our model, as described previously (11).

Cytokines have been implicated in the induction of the acute phase response. Most studies devoted to the exploration of the role of cytokines and hormones in inducing acute phase proteins have been carried out in cell culture systems and have shown direct cytokine effects. Prominent stimulatory functions have been ascribed to TNF- $\alpha$, IL-1 $\beta$, IL-6, and glucocorticoids (17, $29,33)$. Two types of acute phase genes with different 


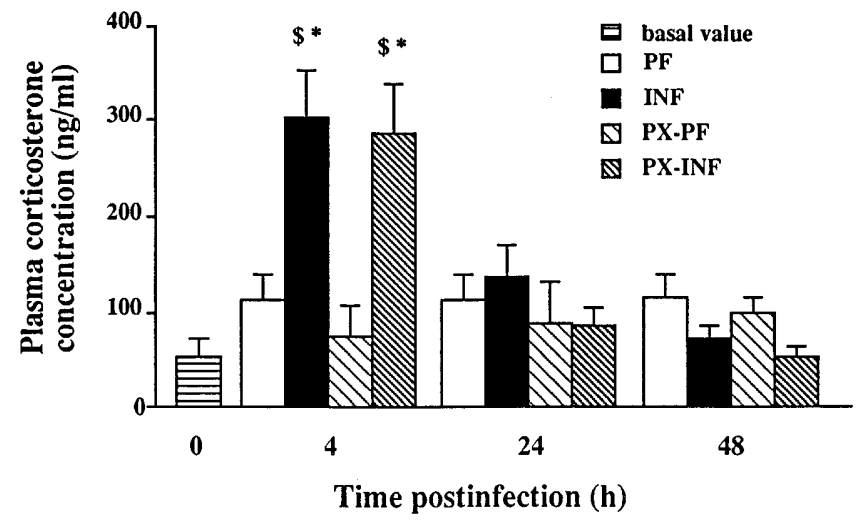

Fig. 4. Effect of PX treatment on plasma corticosterone concentration 4, 24, and $48 \mathrm{~h}$ after infection. Plasma corticosterone levels were assayed by RIA. Values are means \pm SE for $6-11$ animals. $\$ \mathrm{P}<0.05$ vs. basal value. $* P<0.05$ vs. respective pair-fed animals.

cytokine controls have been described as follows: those that respond to IL-1 $\beta$ and TNF- $\alpha$ such as AGP and those that respond to I L- 6 such as A2M and fibrinogen for the rat $(8,29,33)$. Moreover, to achieve maximally regulated expression of some proteins, a combination of cytokines and glucocorticoids is often required.

The qualitative pattern of the regulated positive acute phase proteins observed with PX treatment during the acute phase in our study was characteristic of that generally described in vitro. The first protein affected both at the transcriptional level and plasma concentration by the treatment was AGP, which is recognized to be regulated mainly by TNF $-\alpha$ and IL-1 $\beta$ $(8,29,33)$. These results were consistent with the findings of Sharma et al. (42) using TNF- $\alpha$ monoclonal antibody treatment of endotoxemia in rats. Glucocorticoids al one are able to induce AGP (31), but there was no difference in the corticosterone level in treated and nontreated infected rats. Although AGP is minimally affected by I L-6 al one (31), some synergistic action with TNF $-\alpha$ and IL-I can occur (8).

By contrast, A2M and fibrinogen plasma levels were not initially decreased by PX treatment, which did not modify A2M mRNA levels but slightly decreased those of fibrinogen. Because I L- 6 secretion was not abol ished by $\mathrm{PX}$, these results are in agreement with numerous studies attributing a predominant role of IL-6 in inducing these two proteins $(3,31,37)$. Moreover, in vitro data have shown that TNF- $\alpha$ and IL-1 did not alter either the expression or the synthesis of A2M (4). The regulation of fibrinogen gene expression seems more complex, since IL-1 inhibits its stimulation and this inhibitory effect is reversed by endogenous I L-1ra (37). Moreover, glucocorticoids are required to achieved a maximal IL-6 response for A2M but not for fibrinogen (31).

The decline in plasma albumin and mRNA levels appears not to be affected by PX treatment of septic rats, as shown with anti-TNF- $\alpha$ antibody treatment of endotoxemic rats (42). Anti-I L-1 receptor antibody administration before turpentine injection in mice failed to restore al bumin plasma concentration (21). However, in vivo administration of TNF- $\alpha, \mathrm{IL}-1 \beta$, or IL- 6 is able to decrease albumin synthesis $(5,10,20)$, and the combination of these cytokines, especially IL-1 $\beta$ and IL-6, resulted in an additive downregulation of albumin synthesis in vitro (4). On the other hand, glucocorticoids are known to increase albumin synthesis (24) and could partially antagonize the inhibitory effect of cytokines. Taken together, these data suggest that a small amount of any cytokine is enough to inhibit albumin synthesis and/or that unknown mediators or mechanisms play a predominant role in determining hypoal buminemia.

During the chronic phase, the levels of AGP, A2M, and fibrinogen were significantly decreased in infected rats treated with PX compared with nontreated animals, indicating perhaps the rapid recovery of treated animals. No evidence of return to normal levels of al bumin appeared at the end of the study, showing that al bumin constitutes a poor index of outcome. However, mRNA levels tend to increase at the end of the experiment. The function of the decreased plasma level of albumin, and more generally of the negative acute phase proteins, is not yet clear and deserves further studies (2).

In summary, in a rat model of long-lasting sepsis, the administration of $\mathrm{PX}$ before infection inhibited circulating TNF $-\alpha$, depressed plasma I L- $1 \beta$ and I L- 6 levels, but had no effect on corticosterone levels. Moreover, PX treatment reduced anorexia and body weight loss, suppressed muscle protein wasting, and modulated the acute phase response. Our results suggest that glucocorticoids exert their action not directly, but mainly in

Table 3. Effect of PX treatment on $\alpha_{1}$-acid glycoprotein, $\alpha_{2}$-macroglobulin, fibrinogen, and al bumin levels 2 and 6 days postinfection

\begin{tabular}{|c|c|c|c|c|c|c|c|c|}
\hline & \multicolumn{8}{|c|}{ Days Postinfection } \\
\hline & $\mathrm{PF}$ & INF & PX-PF & PX-INF & $\mathrm{PF}$ & INF & PX-PF & PX-INF \\
\hline
\end{tabular}

Values are means \pm SE for 4- 6 animals. $* P<0.05$, one-way ANOVA vs. respective pair-fed controls. †P $<0.05$, one-way ANOVA vs. respective infected animals. 
A

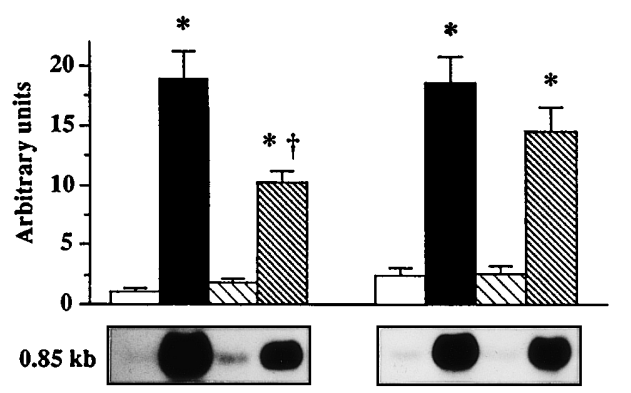

d2
B

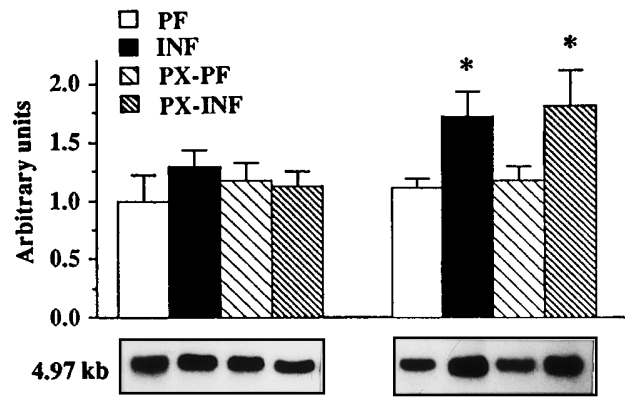

d2

d6

Fig. 5. Effect of PX treatment on mRNA levels for $\alpha_{1}$-acid glycoprotein (A) and $\alpha_{2}$-macroglobulin (B). RNA was extracted from liver of infected rats (INF) and their pair-fed controls (PF) and of infected rats treated with $P X$ (PX-INF) and their pair-fed control treated with PX (PX-PF). Samples $(20 \mu \mathrm{g})$ were el ectrophoresed, transferred to nylon membranes, and hybridized with [32P]cDNAs encoding $\alpha_{1}$-acid glycoprotein and $\alpha_{2}$-macroglobulin. After stripping of the probes, blots were rehybridized with an $18 \mathrm{~S}$ ribosomal oligonucleotide. Data were corrected for $18 \mathrm{~S}$ rRNA abundance to take into account variations in RNA loading. Values are means \pm SE for 4 or 5 rats. All data were referred to pair-fed day 2 value, which was arbitrarily chosen to equal 1 . Representative Northern blots are also shown. d2, 2 days postinfection; $d 6,6$ days postinfection. $* P<0.05$ vs. respective $P F$ animals. $† P<0.05$ vs. respective animals without PX treatment.

combination with, other mediators. Moreover, our results underline in vivo that regulation of acute phase protein expression can occur at different levels according to the protein $(17,33)$.

The effects of PX treatment of infected rats shown in this study support the hypothesis of an important role of TNF- $\alpha$ in the regulation of protein metabolism during sepsis. However, further experiments are needed to understand the link between the very early and transient TNF $-\alpha$ secretion and the long-lasting effects observed in muscle and liver protein metabolism. Despite the complexity of the cytokine and hormonal network, the present study demonstrates in vivo that individual mediators have specific effects on particular

A

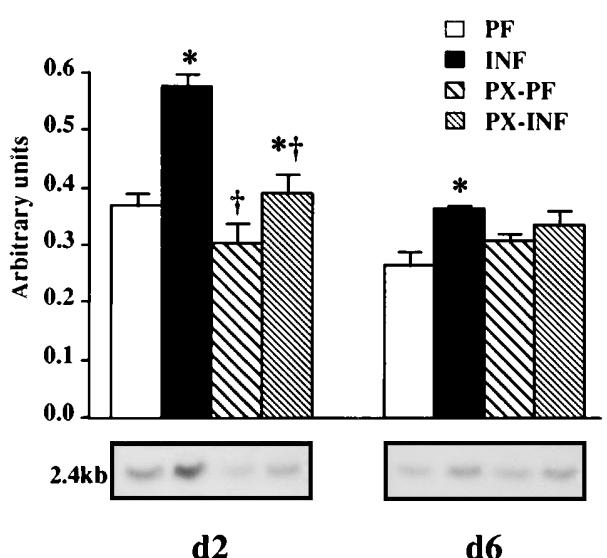

acute phase proteins, making AGP a better index of recovery after PX treatment than A2M. This emphasizes again that acute phase proteins do not always respond in unison in disease states. Clearly, the role of the various acute phase proteins and the regulation of the acute phase response have to be evaluated in detail in various diseases before acute phase proteins become a practical clinical diagnostic and prognostic tool.

Wethank Dr. J acques Dornand (Institut National de la Santé et de la Recherche Médicale U65, Montpellier, France) and Dr. André Mazur and Corinne Malpuèche (Institut National de la Recherche Agronomique, Clermont-Ferrand, Theix, France) for interleukin- 6 bioassay. We thank Dr. H. Baumann (Department of Molecular and Cellular Biology, Roswell Park Cancer Institute, Buffalo, NY) for providing

\section{B}

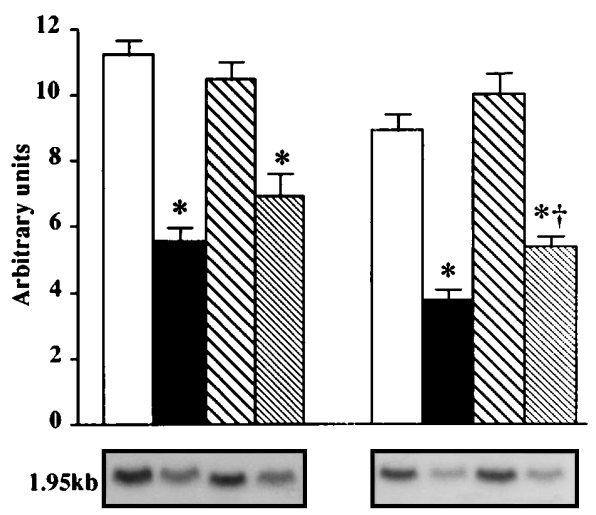

d2 d6

Fig. 6. Effect of $P X$ treatment on mRNA levels for fibrinogen (A) and albumin (B). RNA was extracted from liver of infected rats (INF) and their pair-fed controls (PF) and of infected rats treated with PX (PX-INF) and their pair-fed control treated with PX (PX-PF). Samples $(20 \mu \mathrm{g})$ were electrophoresed, transferred to nylon membranes, and hybridized with [ $\left.{ }^{32} \mathrm{P}\right] \mathrm{CDN}$ As encoding fibrinogen and al bumin. After stripping of the probes, blots were rehybridized with an 18S ribosomal ol igonucleotide. Data were corrected for $18 \mathrm{~S}$ rRNA abundance to take into account variations in RNA loading. Values are means \pm SE for 4 or 5 rats. All data were referred to pair-fed day 2 value, which was arbitrarily chosen to equal 1 . Representative Northern blots are also shown. $* \mathrm{P}<0.05$ vs. respective PF animals. $\dagger \mathrm{P}<0.05$ vs. respective animals without $\mathrm{PX}$ treatment. 
$\alpha$-fibrinogen cDNA and Drs. Y. Akira and K. Nakamura (Department of Applied Biological Sciences, Nagoya University, Nagoya, J apan) for providing albumin CDNA.

This study was supported by Clintec Technologies, the French Ministère de l'Enseignement Supérieur et de la Recherche, and the Institut National de la RechercheAgronomique.

Address for reprint requests: $C$. Obled, Institut National de la RechercheAgronomique, Unité d'Etude du M étabolismeAzoté, 63122 Ceyrat, France.

Received 5 May 1998; accepted in final form 13 J uly 1998.

\section{REFERENCES}

1. Aarden, L. A., E. R. De Groot, O. L. Schaap, and P. M. Lansdorp. Production of hybridoma growth factor by human monocytes. Eur. J . Immunol. 17: 1411-1416, 1987.

2. Aldred, A. R., and G. Schreiber. The negative acute phase proteins. In: AcutePhaseProteins. Mol ecular Biology, Biochemistry, and Clinical Applications, edited by A. Mackiewicz, I. Kushner, and H. Baumann. London: CRC, 1993, p. 22-35.

3. Andus, T., T. Geiger, T. Hirano, T. Kishimoto, and P. C. Heinrich. Action of recombinant human interleukin-6, interleukin-1 $\beta$ and tumor necrosis factor $\alpha$ on the mRNA induction of acute phase proteins. Eur. J . I mmunol. 18: 739- 746, 1988.

4. Andus, T., T. Geiger, T. Hirano, T. Kishimoto, T. Tran-Thi, and P. C. Heinrich. Regulation of synthesis and secretion of major acute-phase proteins by recombinant human interleukin- 6 (BSF-2/IL-6) in hepatocytes primary cultures. Eur. J . Biochem. 173: 287-293, 1988

5. Ballmer, P. E., M. A. McNurlan, I. Grant, and P. J . Garlick. Down-regulation of albumin synthesis in the rat by human recombinant interleukin-1 $\beta$ or turpentine and the response to nutrients. J PEN J . Parenter. Enteral Nutr. 19: 266-270, 1995.

6. Barton, B. E. The biological effects of interleukin 6. Med. Res. Rev. 16: 87-109, 1996

7. Baumann, H., R. E. Hill, D. N. Sauder, and G. P. J ahreis. Regulation of major acute-phase plasma proteins by hepatocyte stimulating factors of human squamous carcinoma cells. J . Cell Biol. 102: 370-383, 1986.

8. Baumann, H., K. K. Morella, and G. H. W. Wong. TNF- $\alpha$, IL-1- $\beta$, and hepatocyte growth factor cooperate in stimulating specific acute phase plasma protein genes in rat hepatoma cells. J . Immunol. 151: 4248-4257, 1993.

9. Birch, H. E., and G. Schreiber. Transcriptional regulation of plasma protein synthesis during inflammation. J . Biol. Chem. 261: 8077-8080, 1986

10. Brenner, D. A., M. Buck, S. P. Feitelberg, and M. Chojkier. Tumor necrosis factor- $\alpha$ inhibits albumin gene expression in a murine model of cachexia. J . Clin. Invest. 85: 248-255, 1990.

11. Breuillé, D., M. Arnal, F. Rambourdin, G. Bayle, D. Levieux, and C. Obled. Sustained modifications of protein metabolism in various tissues in a rat model of long-lasting sepsis. Clin. Sci. (Colch.) 94: 413-423, 1998.

12. Breuillé, D., M. C. Farges, F. Rosé, M. Arnal, D. Attaix, and C. Obled. Pentoxifylline decreases the body weight loss and muscle protein wasting characteristics of sepsis. Am. J . Physiol 265 (Endocrinol. Metab. 28): E660-E666, 1993.

13. Charters, Y., and R. F. Grimble. Effect of recombinant human tumor necrosis factor al pha on protein synthesis in liver, skel etal muscle and skin of rats. Biochem. J . 258: 493-497, 1989.

14. Chomczynski, P., and N. Sacchi. Single-step method of RNA isolation by acid guanidinium thiocyanate-phenol-chloroform extraction. Anal. Biochem. 162: 156- 159, 1987.

15. Cooney, R. N., E. Owens, C.J urasinski, K. Gray, J . Vannice, and T. C. Vary. Interleukin-1 receptor antagonist prevents sepsis-induced inhibition of protein synthesis. Am. J. Physiol 267 (Endocrinol. Metab. 30): E636-E641, 1994.

16. Cory, A. H., T. C. Owen, J . A. Barltrop, and J . G. Cory. Use of aqueous soluble tetrazolium/formazan assay for cell growth assays in culture. Can. Commun. Dis. Rep. 3: 207-212, 1991.

17. Fey, G. H., G. M. Hocke, D. R. Wilson, J . A. Ripperger, T. S. C. J uan, M. Z. Cui, and G. J . Darlington. Cytokines and the acute phase response of the liver. In: Biology and Pathobiology (3rd ed.), edited by I. M. Arias. New York: Raven, 1994, p. 113- 143.
18. Fong, Y., K. J . Tracey, L. L. Moldawer, D. G. Hesse, K. B. Manogue,. J . S. Kenney, A. T. Lee, G. C. Kuo, A. C. Allison, S. F. Lowry, and A. Cerami. Antibodies to cachectin/tumor necrosis factor reduce interleukin 1beta and interleukin 6 appearance during lethal bacteremia. J. Exp. Med. 170: 1627-1633, 1989.

19. Gehring, M. R., B. R. Shiels, W. Northemann, M. H. L. de Bruijn, C. C. Kan, A. C. Chain, D. J . Noonan, and G. H. Fey. Sequence of rat liver $\alpha 2$-macrogl obul in and acute phase control of its messenger RNA. J . Biol. Chem. 262: 446-454, 1987.

20. Geiger, T., T. Andus, J . Klapproth, T. Hirano, T. Kishimoto, and P. C. Heinrich. Induction of rat acute-phase proteins by interleukin 6 in vivo. Eur. J . Immunol. 18: 717-721, 1988.

21. Gershenwald, J . E., Y. Fong, T. J . Fahey III, S. E. Calvano, R. Chizzonite, P. L. Killian, S. F. Lowry, and L. L. Moldawer. Interleukin 1 receptor blockadeattenuates the host inflammatory response. Proc. Natl. Acad. Sci. USA 87: 4966-4970, 1990.

22. Givalois, L., J . Dornand, M. Mekaouche, M. D. Solier, A. F. Bristow, G. Ixart, P. Siaud, I. Assenmacher, and G. Barbanel. Temporal cascade of plasma level surges in ACTH corticosterone, and cytokines in endotoxin-challenged rats. Am. J. Physiol. 267 (Regulatory Integrative Comp. Physiol. 36): R164R170, 1994.

23. Hall-Angeras, M., U. Angeras, O. Zamir, P. O. Hasselgren, and $\mathbf{J}$. E. Fischer. Interaction between corticosterone and tumor necrosis factor stimulated protein breakdown in rat skeletal muscle, similar to sepsis. Surgery 108: 460-466, 1990.

24. Hutson, S. M., C. Stinson-Fisher, R. Shiman, and L. S. J efferson. Regulation of albumin synthesis by hormones and amino acids in primary cultures of rat hepatocytes. Am. J. Physiol. 252 (Endocrinol. Metab. 15): E291-E298, 1987.

25. I watsuki, N., T. Hattori, Y. Iswasaki, M. Nakano, and K. Nakamura. A complete rat serum albumin CDNA clone directly identified by immunological screening of CDNA expression library. Agric. Biol. Chem. 51: 379- 384, 1987.

26. J ohnson, R. W., M. J . Propes, and Y. Shavit. Corticosterone modulates behavioral and metabolic effects of lipopolysaccharide. Am. J . Physiol. 270 (Regulatory I ntegrative Comp. Physiol. 39): R192-R198, 1996.

27. J urassinski, C. V., L. Kilpatrick, and T. C. Vary. Amrinone prevents muscle protein wasting during chronic sepsis. Am. J. Physiol. 268 (Endocrinol. Metab. 31): E491-E500, 1995.

28. Klapproth, J ., J . Castell, T. Geiger, T. Andus, and P. C. Heinrich. Fate and biological action of human recombinant interleukin $1 \beta$ in the rat in vivo. Eur. J. Immunol. 19: 14851490, 1989.

29. Koj, A., J . Gauldie, and H. Baumann. Biological perspectives of cytokine and hormone networks. In: Acute Phase Proteins. Molecular Biology, Biochemistry, and Clinical Applications, edited by A. Mackiewicz, I. Kushner, and H. Baumann. London: CRC, 1993, p. 276-283.

30. LeMay, L. G., A. J . Vander, and M. J . Kluger. The effects of pentoxifylline on lipopolysaccharide (LPS) fever, plasma interleukin-6 (I L6), and tumor necrosis factor (TNF) in the rat. Cytokine 2: 300-306, 1990.

31. Marinkovic, S., G. P.J ahreis, G. G. Wong, and H. Baumann. IL-6 modulates the synthesis of a specific set of acute phase plasma proteins in vivo. J . I mmunol. 142: 808-812, 1989.

32. Oldenburg, H. S. A., M. A. Rogy, D. D. Lazarus, K. J . Van Zee, B. P. Keeler, R. Chizzonite, S. F. Lowry, and L. L. Moldawer. Cachexia and the acute-phase protein response in inflammation are regulated by interleukin-6. Eur. J . I mmunol. 23: 1889-1894, 1993.

33. Pannen, B. H. J., and J . L. Robotham. The acute phase response. New Horizons 3: 183-197, 1995.

34. Pradier, P., and M. Dalle. Effects of corticotrophin-releasing factor and vasopressin on plasma adrenocorticotrophin molecular forms, aldosterone and corticosterone in young and adult rats and rabbits. Reprod. Fertil. Dev. 8: 111-116, 1996.

35. Pruitt, J . H., E. M. Copeland., and L. L Moldawer. I nterleukin-1 and interleukin-1 antagonism in sepsis, systemic inflammatory response syndrome, and septic shock. Shock 3: 235-251, 1995. 
36. Ricca, G. A., R. W. Hamilton, J . W. McLran, A. Conn, J . E. Kalinyak, and J . M. Taylor. Rat $\alpha 1$-acid glycoprotein mRNA. Cloning of double-stranded CDNA and kinetics of induction of mRNA levels following acute inflammation. J . Biol. Chem. 256: 10362- 10368, 1981.

37. Rokita, H., R. Neta, and J . D. Sipe. Increased fibrinogen synthesis in mice during the acute phase response: cooperative interaction of interleukin-1, interleukin-6, and interleukin-1 receptor antagonist. Cytokine 5: 454-458, 1993.

38. Schade, U. F. Pentoxifylline increases survival in murine endotoxin shock, and decreases formation of tumor necrosis factor. Circ. Shock 31: 171-181, 1990.

39. Schandené, L., P. Vandenbussche,A. Crusiaux, M. L. Alègre, D. Abramowicz, E. Dupont, J . Content, and M. Goldman. Differential effects of pentoxifylline on the production of tumour necrosis factor-al pha (TNF $\alpha$ ) and interleukin-6 (IL-6) by monocytes and T cells. I mmunol ogy 76: 30-34, 1992.

40. Schreiber, G., G. Howlett, M. Nagashima, A. Millership, H. Martin, J . Urban, and L. Kotler. The acute phase response of plasma protein synthesis during experimental inflammation. J . Biol. Chem. 257: 10271-10277, 1982.

41. Semmler, J ., U. Gebert, T. Eisenhut, J. Moeller, M. M. Schonharting, A. Allera, and S. Endres. Xanthine derivatives: comparison between suppression of tumour necrosis factoralpha production and inhibition of CAMP phosphodiesterase activity. I mmunol ogy 78: 520-525, 1993.
42. Sharma, R. J ., D. C. Macallan, P. Sedgwick, D. G. Remick, and G. E. Griffin. Kinetics of endotoxin-induced acute-phase protein gene expression and its modulation by TNF- $\alpha$ monoclonal antibody. Am. J . Physiol. 262 (Regulatory Integrative Comp. Physiol. 31): R786-R793, 1992.

43. Van der Poll, T., and S. F. Lowry. Tumor necrosis factor in sepsis: mediator of multiple organ failure or essential part of host defense? Shock 3: 1- 12, 1995.

44. Vary, T. C., and S. R. Kimball. Regulation of hepatic protein synthesis in chronic inflammation and sepsis. Am. J. Physiol. 262 (Cell Physiol. 31): C445- C452, 1992.

45. Yang, Z. J ., M. Koseki, M. M. Meguid, J . R. Gleason, and D. Debonis. Synergistic effect of rhTNF- $\alpha$ and rhlL-1 alpha in inducing anorexia in rats. Am. J. Physiol. 267 (Regulatory IntegrativeComp. Physiol. 36): R1056-R1064, 1994.

46. Zamir, O., P. O. Hasselgren, S. L. Kunkel, J . Frederick, T. Higashiguchi, and J . E. Fischer. Evidence that tumor necrosis factor participates in the regulation of muscle proteolysis during sepsis. Arch. Surg. 127: 170-174, 1992.

47. Zamir, O., P. O. Hasselgren, D. Von Allmen, and J. E. Fischer. In vivo administration of interleukin- $1 \alpha$ induces muscle proteolysis in normal and adrenal ectomized rats. Metabol ism 42: 204-208, 1993.

48. Zamir, O., W. O'Brien, R. Thompson, D. C. Bloedow, J . E. Fischer, and P. O. Hasselgren. Reduced muscle protein breakdown in septic rats following treatment with interleukin-1 receptor antagonist. Int. J . Biochem. 26: 943-950, 1994.

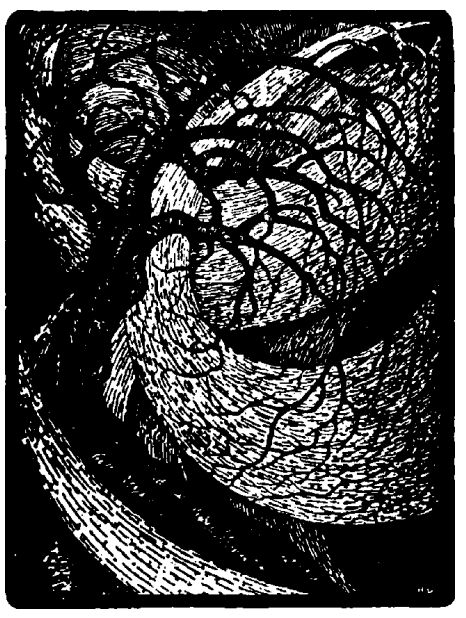

